\title{
O NASCIMENTO DO INQUÉRITO NA TRAGÉDIA DE "ÉDIPO-REI": UMA LEITURA FOUCAULTIANA
}

\author{
Fabiano Incerti* \\ fabiano.incerti@yahoo.com
}

RESUMO Michel Foucault considera a tragédia de "Édipo-Rei" como uma história de saber-poder da qual emerge, no nascente direito grego, a prática do inquérito (enquête). Para ele, a trama discorre acerca da repressão que pesa sobre os sistemas ocidentais de verdade. Se de alguma maneira há uma determinação edipiana no Ocidente, esta não está no nível do desejo, como acredita a psicanálise, mas se encontra no interior do sistema de coações que sustenta, desde a Grécia, o discurso sobre a verdade e que se expressa a partir da exigência política, jurídica e religiosa de converter o acontecimento num fato conservado definitivamente por meio da comprovação das testemunhas. Édipo é, em síntese, uma história da verdade, em que há um crime que precisa ser desvendado e um criminoso a ser punido, e cada uma das partes da investigação atende rigorosamente às leis da época.

Palavras-chave Inquérito, Testemunha, Verdade, "Édipo-Rei”, Michel Foucault.

ABSTRACT Michel Foucault considers the tragedy "Oedipus, the King" as a story of knowledge-power from which emerges, in the nascent Greek law, the practice of inquiry (enquete). For him, the plot talks about the repression that weighs on Western systems of truth. If, somehow, there

* Pontifícia Universidade Católica do Paraná (PUC-PR). Artigo recebido em 02/12/2014 e aprovado em 19/12/2015. 
is an Oedipal determination in the West, this is not at the level of desire, as psychoanalysis believes, but it is within the constraints holding system, from Greece, the discourse about truth and that is expressed from the political, legal and religious requirement to convert the event into a fact saved definitely by the evidence of witnesses. Oedipus is, in short, a story of truth, in which there is a crime that needs to be unravelled and a criminal to be punished, and each part of the research caters strictly the laws from that time.

Keywords Inquiry, Witness, Truth, "Oedipus, the King”, Michel Foucault.

\section{Introdução}

A história de Édipo significa, para Michel Foucault, o momento de surgimento da prática jurídica do inquérito (enquête). Para ele, com o passar do tempo, tal prática foi racionalizada até se tornar decisiva para a história do Ocidente, seja para a criação dos modelos judiciários que se seguiram, seja para o nascimento de outros saberes, tais como os filosóficos, os retóricos e os empíricos (Foucault, 2002, p. 54). Diferentemente da prova (épreuve), que se fundamenta no desafio lançado de um guerreiro a outro e na qual a verdade é definida de maneira mecânica, seguindo métodos ordálicos, o inquérito tem sua base no testemunho; na presença de alguém capaz de relatar o fato e confirmar, a partir de sua própria memória, a verdade.

Foucault fala de pelo menos quatro consequências diretas, no interior da democracia grega, advindas da possibilidade de testemunhar: 1) a modificação nas relações de poder, na medida em que o testemunho transforma-se na possibilidade de opor a verdade ao poder estabelecido; 2) a elaboração e o aprimoramento das formas tradicionais de prova e demonstração, que implicam, em suma, o como, em que condições e com quais regras se produz a verdade; 3) o desenvolvimento da retórica, ou seja, da arte de persuadir; 4) o desenvolvimento de um novo modelo de conhecimento que tem seu fundamento na memória e na investigação.

Temos então, a partir das leituras foucaultianas acerca de Édipo, a oportunidade de observar como tais consequências do procedimento de testemunhar se desdobram e se intensificam no decorrer da peça. Podemos entender também de que forma, para um conjunto de pensadores, ${ }^{1}$ a tragédia 
de Sófocles se desdobra por um viés investigativo, sugerindo que a caça ao assassino de Laio segue rigorosamente os termos da lei grega, no que concerne especialmente a seu caráter público e privado. Nesse sentido, nosso objetivo com os parágrafos que se seguem é discutir como na Grécia clássica se estabelece um novo modelo de pesquisa e produção da verdade, que tem sua base nos mecanismos judiciários nascentes do inquérito e do testemunho.

\section{Um paraíso judiciário perfeitamente claro}

Édipo envia Creonte ao oráculo de Delfos para se informar sobre a peste que aflige Tebas. A sugestão do oráculo, trazida por Creonte, é clara: encontrar e punir o culpado do crime, livrando, dessa forma, a cidade da mancha $(\mu i ́ \alpha \sigma \mu \alpha)(95-98){ }^{2}$ Diante dessa situação, que se apresenta na cena de abertura, identificamos duas formas de procedimentos jurídicos comuns que envolvem a denúncia de assassinato no século V. Por um lado, trata-se de uma ação legal particular, pois quem processa por assassinato é o indivíduo e não o Estado, e, por outro, refere-se a uma ação político-legal pública, pois, como sabemos, é um caso de regicídio, e os assassinos, confirma o oráculo, são tebanos.

Foucault extrai desse episódio uma série de elementos jurídicos concernentes à época. Inicialmente, o fato de que a denúncia de assassinato é realizada por um não cidadão. Apolo é quem exige reparação do crime cometido, com o banimento ou a morte do criminoso, para assim vingar "o sangue que maculou a cidade" (101). Essa forma de denúncia legal privada é uma técnica aceita e empregada, entretanto, por não ser cidadão e por ser um crime já prescrito, o deus está impedido de "entrar com uma ação" junto ao conselho ou à assembleia, como de costume para esses casos. Resta-lhe somente informar ( $\mu \eta v v ́ \omega)$ os elementos que acha pertinentes serem levados em conta no decorrer da investigação. As informações são avaliadas pela assembleia e, caso sejam consideradas verdadeiras, é eleito um grupo de inves-

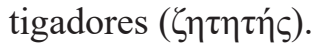

O homicídio é considerado o delito privado mais grave do direito grego (Gernet, 2001, pp. 83-84). Ele diz respeito, em geral, a todo tipo de atentado à pessoa ou à coisa de outrem, ao passo que o sacrilégio e a traição são tidos como os delitos públicos mais significativos. Numa sociedade que vê se estruturar, cada vez mais, o pensamento acerca de um "sujeito de direitos", a 
noção de "ser culpado" ( $\dot{\alpha} \delta$ « $\tilde{\omega})$, que exprime a ideia de um delito intencional, designa, primordialmente, a ofensa aos interesses individuais. Contudo, para que obtenha alguma relevância no território da cidade, é preciso que o sentimento de injustiça ultrapasse o espaço estritamente individual e comece a ser compartilhado pela totalidade do grupo.

Nas situações de homicídio, a coletividade se restringe ao grupo da cidade, excluindo, dessa forma, para fins de julgamento, os crimes cometidos em país estrangeiro. Já a cidade, concebida como uma sociedade organizada, torna-se igualmente um lugar religioso, que afirma sua solidariedade no sentimento de comunhão. Por ocasião de uma morte violenta, é por meio desse sentimento que a mácula tem a força de contaminar todo o seu território. $\mathrm{O}$ interdito ( $\pi \rho o ́ \rho \rho \eta \sigma ı)$ ) assume então a função, no interior do rito judiciário, de remoção do culpado da comunidade sagrada.

A leitura foucaultiana compreende a trama que abarca Édipo como um crime no duplo aspecto: inicialmente de infração às leis fundamentais da cidade e, depois, de profanação religiosa; dois aspectos que são, para o pensador francês, completamente indissociáveis no pensamento e na cultura grega. $\mathrm{O}$ procedimento judiciário, no século $\mathrm{V}$, é percebido como embutido no interior da ação divina e do rito religioso do oráculo (Foucault, 2012b, p. 50).

O caráter judicial torna-se, então, completamente reconhecível na peça por um conjunto de expressões específicas utilizadas por Édipo ao cumprir os ritos prescritos na tradição. Primeiramente, ele absolve os que testemunhem contra eles mesmos (227-229), depois promete uma recompensa a toda pessoa que forneça alguma informação sobre o assassino de Laio (232) e, por fim, amaldiçoa aqueles que escondem o que sabem (235-239). Tais atitudes vão garantir o sentido dramático do enredo. Não obstante, elas não dizem respeito somente à economia trágica da trama, antes atestam exatamente, passo a passo, os procedimentos contidos no interior do direito clássico ateniense para esse tipo denúncia.

Ante a delação de Apolo, de que os assassinos de Laio devem ser encontrados para, assim, cessar o flagelo da cidade, Édipo responde: "eu mesmo, remontando a sua origem, hei de torná-los evidentes sem demora” (132). Com essa afirmação, a investigação é efetivamente iniciada e o herói de Sófocles

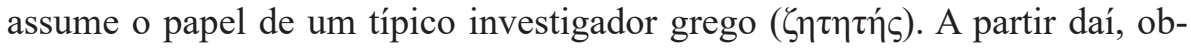
serva Foucault, o inquérito vai se desenrolar atendendo à literatura jurídica ateniense (Foucault, 2012b, p. 52).

A apreciação perspicaz realizada por Segal (2001, pp. 73-77) confirma o perfil investigativo de Édipo, antes mesmo de ele tomar formalmente para si este papel junto ao povo de Tebas. No início do prólogo, o anúncio feito a 
todo o povo por ele, de que já teria enviado Creonte a Delfos a fim de buscar uma solução junto ao oráculo de Apolo, é uma prova sólida de sua energia e preocupação. Isso se concretiza no diálogo com o sacerdote, em que se vê sua força impaciente quando afirma que já conta "muitos dias transcorridos desde a partida dele (Creonte), sinto-me inquieto com essa demora estranha, demasiado longa" (73-75). No imediato momento da chegada de seu cunhado com a resposta do oráculo, o sacerdote se afasta e ele detém o comando, conduzindo, com espírito esperançoso e urgente, o primeiro dos interrogatórios, que se repetirão por várias vezes até o fim da peça (79).

Nas análises da cena que antecede a entrada do coro, Foucault mostra que Sófocles faz da tragédia de Édipo un paradis judiciaire parfaitement clair (Foucault, 2012b, p. 49). Primeiramente, a denúncia, realizada por um não cidadão, de um assassinato cometido sobre o território da cidade, atendendo, assim, a uma ação de delito privado. Depois, a revelação de que o crime é um regicídio e, por isso, refere-se igualmente a uma ação legal pública. Em terceiro lugar, no intuito de purificar a cidade, a exigência, por parte do deus, de punição para o culpado ainda desconhecido, o que recorda a relação intrínseca que se mantém, no mundo grego, entre as leis e a religião. Em seguida, a denúncia é aceita pela assembleia, que determina então a constituição de uma comissão de investigação, papel que Édipo assume integralmente. E, por fim, como sinal do início da busca pelo culpado, Édipo se utiliza das medidas preliminares empregadas na época. Elas impõem que um familiar, por meio de um arauto, anuncie, em praça pública, as circunstâncias da morte e solicite as informações necessárias ( $\mu \eta v v ́ \omega)$.

Mas pode Édipo assumir a responsabilidade investigativa desse crime, embora não seja parente da vítima? Esse aspecto judicial ganha em Bernard Knox uma versão que merece ser analisada (2002, pp. 70-74). A passagem na qual Édipo procura enfatizar sua relação íntima com Laio, "hei de lutar por ele como por meu pai" (264), é, para o estudioso inglês, uma tentativa de o protagonista estabelecer uma base relacional com o rei assassinado, a fim de garantir seu direito de procurar e processar o responsável pelo delito. É importante lembrarmos também que Apolo, com a revelação oracular, questiona o próprio poder de Édipo e isso, sem dúvida, justifica tanto seu empenho como sua pressa em resolver o problema (137-140).

Pela maldição proclamada por Édipo na praça do mercado, Sófocles recorda ao público do teatro ateniense as práticas legais presentes numa acusação de assassinato ( $\delta$ ín $\varphi$ póvov), quando o réu é mencionado pelo nome e recebe, do magistrado que preside o julgamento preliminar, o interdito formal de acesso a templos, sacrifícios, orações e lugares públicos. 


\section{O inquérito do cego Tirésias}

$\mathrm{Na}$ entrada da primeira testemunha a ser interrogada é o coro que, com entusiasmo, saúda a presença de Tirésias, na certeza de que suas palavras serão suficientes para que o assassino do rei se renda ou fuja da cidade: "já vejo aproximar-se quem vai descobri-lo [...]” (297), entoa o canto. Édipo parece não compartilhar dessa euforia e confirma seu pressentimento ao encontrar em Tirésias uma testemunha relutante. Nas suas primeiras palavras, o adivinho contesta sua convocação: "Terrível o saber se ao sabedor é ineficaz. Embora ciente disso me descuidei: jamais teria vindo" (316-318).

Com um sentido técnico-judicial que indica a ação de "comparecer ao tribunal", Édipo se utiliza da expressão grega $\varepsilon i \sigma \varepsilon \lambda \eta ́ n v \theta \alpha \varsigma$ para condenar a inquietante resistência e o inesperado arrependimento de Tirésias por ter vindo ao interrogatório. A resposta do profeta solicitando sua retirada imediata tem igualmente uma conotação jurídica e se refere a uma palavra usual para súplicas de soltura e absolvição (á $\varphi \varepsilon \varsigma \mu$ '). Édipo segue a mesma lógica legal em sua réplica, quando declara a ilegalidade do pedido realizado (oü $\tau$ ' '̌̌vvo $\mu$ '

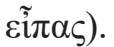

Enquanto a cólera toma conta dos dois adversários, deparamo-nos com uma série de argumentos de caráter jurídico que vão aparecendo no decorrer do diálogo (Knox, 2002, pp. 70-72). Tirésias recusa-se a falar a verdade que lhe é conhecida e, por isso, seguem-se as ameaças de Édipo. Elas começam por censurá-lo pelo mal que faz a seus concidadãos e para a própria cidade: "Que dizes? Sabes a verdade e não a falas? Queres trair-nos e extinguir nossa cidade?" (330-331). O silêncio e a obscuridade das poucas palavras ditas pelo profeta fazem Édipo pronunciar contra ele a acusação, comprovando que uma das principais características do tribunal ático é o ataque. O rei incrimina-o pelo assassinato de Laio, já que se nega a falar e, falando, servese somente de enigmas: "[...] Fica sabendo que em minha opinião articulaste o crime e até o consumaste!" (346-347). E, ademais, Édipo não demora em relacionar Creonte e Tirésias, insinuando uma cumplicidade na execução do delito e, consequentemente, de conspiração contra o Estado: "São tuas estas invenções, ou de Creonte?" (378). Diante dessa denúncia, agora é o profeta que novamente o confronta e revela que é Édipo o autor do crime. "Pois ouve bem: és o assassino que procuras!" (362).

Numa estratégia comum de defesa, Édipo, relembrando o caso da Esfinge, compara seus serviços prestados à cidade com os do adversário. Naquele momento de crise extrema, enquanto Tirésias silenciava, Édipo, um estrangeiro, arriscava sua vida para salvar o povo: "por que silenciaste diante 
dos tebanos ansiosos por palavras esclarecedoras na época em que a Esfinge lhes propunha enigmas?" (391-392).

A resposta de Tirésias para as afrontas de Édipo mostra a argumentação típica de alguém capaz de tomar conta de sua própria defesa. Ele depõe que não é nem escravo nem estrangeiro para ser considerado, como propõe Édipo,

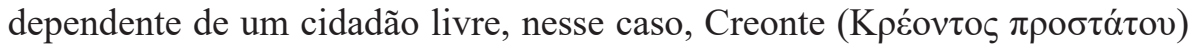
(410-411). Reivindica, sobretudo, ao melhor estilo forense, direitos iguais no que se refere ao livre discurso, "embora sejas rei tenho direito, Édipo, de responder-te, pois me julgo igual a ti" (408-409). O profeta conclui, valendose de mais um artifício comum das salas de audiência atenienses. Empregando

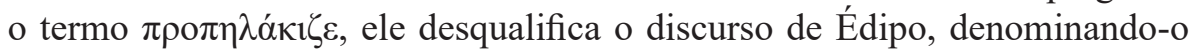
de ultrajante. Tendo por base as mesmas características judiciais e seguindo certo padrão de resposta corriqueiro aos tribunais, Édipo, enfurecido, interpela: "Tolerarei tais impropérios vindos dele?" (429). Em seguida, despede Tirésias, que, por sua vez, repreende-o: "não teria vindo aqui se não me man-

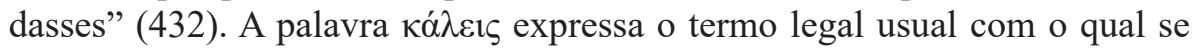
intima uma testemunha para depor no julgamento.

Para Foucault, a tragédia de Édipo é percorrida pelo esforço de toda a cidade para transformar em fatos a dispersão enigmática dos eventos humanos e das ameaças divinas (2011, p. 179). No entanto, todos os testemunhos se furtam e mesmo a testemunha ocular, da qual se tem rumor, não saberia dar nenhuma informação útil. Resta a Édipo somente a possibilidade de interrogar o divino profeta. Canta o coro que Tirésias é o duplo humano do

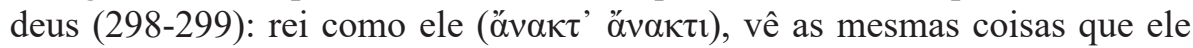
( $\tau \alpha v^{\prime} \theta^{\prime}$ ó $\left.\rho \tilde{\omega} v \tau^{\prime}\right)$ (284). Pela força desse poder, confronta Édipo a partir de sua posição: "Sou livre; trago em mim a impávida verdade!" (356). A palavraverdade pronunciada por ele é, portanto, sua própria autoridade. Em si, ela sustenta uma espécie de lei natural, em que cada previsão é habitada por um poder inato da verdade. O verbo $\lambda \dot{\varepsilon} \gamma \omega$ saindo de sua boca basta para que seu dizer constitua a lei e garanta a verdade (412).

Ao interrogar Tirésias, Édipo, enfurecido, esquece-se daquilo que ele mesmo enfatiza quando afirma que "[...] ninguém detém poder bastante para constranger os deuses a mudar seus altos desígnios" (280-281). Por isso, pressionado pelo interrogador a falar, o adivinho contesta: “[...] não me considero teu servidor, mas de Loxias, deus-profeta [...] (410-411). ${ }^{3}$ O sistema políticojudiciário tem poder para extorquir de forma legítima, como observaremos 
no fim da peça, uma confissão, um testemunho ou uma declaração, contudo, a negação de Tirésias em responder, por se considerar servidor dos deuses e igual a Édipo, põe em xeque, por assim dizer, a própria máquina judiciária.

Evidentemente, a fala de Tirésias constitui-se numa predição e isso trará igualmente consequências jurídicas. Ele nomeia o assassino, mas o faz sem provas. Suas palavras são exatamente compatíveis com as de Apolo: um proclama que há a mancha e que é necessário purificar a cidade; o outro diz quem cometeu a mancha e proclama que ele deve ser caçado. Ambos tudo disseram. No entanto, recorda Foucault, às predições complementares "falta uma parte essencial: este duplo de si mesmo que the daria uma realidade visível, que lhe daria corpo no que se passou, que o impediria de ter sido dito

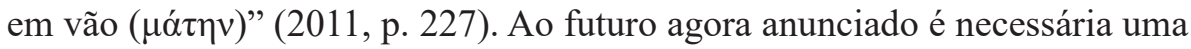
constatação, uma lembrança que atualize o que realmente se passou.

Com o interrogatório de Tirésias, Foucault coloca-nos frente a frente novamente com aquilo que parece permear toda a história: a tensão entre o humano e o divino. Édipo acredita, como evoca o coro, que "Apolo e Zeus têm olhos para tudo" (496), por isso, ainda que intrigado, mas já sem alternativas, convoca o adivinho para a audiência. As acusações proferidas por Tirésias encontram força em sua credibilidade, entretanto, ele é apenas um homem e, além do mais, não carrega consigo evidências do que diz. $\mathrm{Na}$ fúria do fogo cruzado que se trava entre os dois, nenhuma das palavras tem um julgamento que o coro considere como verdadeiro. Se, pouco antes da entrada do profeta, Édipo reconhece a limitação humana diante dos poderes divinos, o outro lado dessa observação tem igualmente um elemento de verdade, pois os deuses revelam coisas a seu próprio tempo, e não demorará muito para Édipo aprender isso. O profeta olha para o deus a quem ele serve, o rei para o reino humano e os motivos humanos que, nesse instante, ele consegue entender.

\section{Um veredito de imparcialidade}

A participação do coro, no primeiro estásimo, é decisiva para a continuidade do julgamento. Falando como uma comissão de juízes, ele interfere tanto hostilizando o ódio surgido no diálogo entre os dois rivais como buscando recuperar a relevância do tema em debate. A cena trágica agora é ocupada por este personagem que é, como descrevem Jean Pierre Vernant e Pierre VidalNaquet, "coletiva e anônima encarnada por um colégio oficial de cidadãos cujo papel é exprimir em seus temores, em suas esperanças, em suas interrogações e julgamentos, os sentimentos dos espectadores que compõem a comunidade cívica [...]" (1999, p. 69). Formado eminentemente por homens, o 
coro é a representação máxima dos valores da cidade, que estão, neste caso, profundamente abalados pelas transgressões cometidas no passado.

O coro tem um papel jurídico preciso no enredo e seu testemunho adquire o caráter de júri. No entanto, no primeiro veredito, ele não consegue decidir qual dos dois adversários tem razão. Afirma, no decorrer do embate, que o rei e o profeta falam somente sob o efeito da cólera (404-405). Pouco mais tarde, depois da partida de Tirésias, ele não sabe o que dizer e sente-se tomado pelas dúvidas que o adivinho pôs em sua mente: "não creio, nem descreio, estou atônito" (484).

Nessa recusa de tomada de decisão, Foucault vê dois diferentes movimentos. Primeiramente, o fato de que não há poder superior ao do coro e, por isso, cabe a ele, como instância julgadora, decidir pela verdade. A parte inicial do canto lírico reconhece a grandeza do oráculo e recorda que dele emanam os "relâmpagos ardentes" (470) que serão lançados como flechas contra o culpado. Este, por sua vez, deve se apressar em fugir, pois não há como escapar da determinação dos deuses. Tais versos ilustram o mundo da fatalidade, do destino, da luz; da verdade que se revela pela transparência do brilho que vem do Parnasso. ${ }^{4}$ Entretanto, o canto continua: “[...] adeja meu espírito indeciso, perplexo entre o passado e o presente" (486-487). Essa citação, como recorda Foucault, é uma declaração oficial do coro, que, mesmo ante a clarividência de Apolo e de Zeus, faz valer seu direito de não acreditar, de não saber, de estar na obscuridade (2012b, p. 58). Na negatividade do reconhecimento dos poderes absolutos de Tirésias, vemos uma manifestação a favor de Édipo: “[...] um mortal, um simples adivinho não pode convencer-me; é inaceitável embora no saber um homem possa ultrapassar os outros muitas vezes" (498-501).

O segundo movimento decorre dessa negação mesma, pois se existem homens que sabem mais que os outros, e esse é o caso de Édipo, é necessário ainda que eles comprovem. O canto lírico exige agora de Tirésias que demonstre os fundamentos de sua delação "[...] jamais, antes de ver ratificada a fala do adivinho darei crédito à acusação lançada contra Édipo" (504-505). A cobrança feita agora a Tirésias revela o prestígio do rei diante do júri, pois, quando da ameaça da Esfinge, ele mostrou sabedoria e amor por Tebas. Aos olhos desses mortais com poder de sentenciar, "uma profecia sem prova, um oráculo sem testemunha não é nada mais que uma suspeita improcedente" (Foucault, 2011, p. 227). Configuram-se, dessa maneira, as bases típicas de uma audiência:

4 Parnasso: "montanha da região de Fócis (Centro-Sul da Grécia), uma das mais altas da Europa. Seu cume coberto de neve era visível de Corínto, Delfos, com seu templo e oráculo famosos, ficava situada nas encostas do Parnasso" (Sófocles, 1989, p. 98). 
Édipo deu as provas necessárias e somente provas poderão valer contra ele. Ademais, ele tem a seu favor as coisas visíveis ( $\varphi \alpha v \varepsilon \rho \alpha ́)$ (508-509).

Há contudo, a parte da análise de Foucault, um terceiro movimento que podemos identificar. Se é verdade que perante o coro Édipo goza de status por seus feitos passados, contra si ele continua tendo as palavras divinas. Isso aponta para a relevante consequência de uma inversão na lógica do julgamento. O coro modifica a ordem da ação e faz com que Édipo, que é o primeiro acusador, transforme-se agora no acusado. As denúncias proferidas por ele contra Tirésias perdem força e a trama se concentra no exame das acusações proferidas pelo adivinho contra ele. Essa perspectiva justifica, por exemplo, o esforço do coro para conseguir, sem sucesso, motivos que comprovem as denúncias contra Édipo: "[...] que controvérsia pode ter havido entre os labdácidas e o descendente de Políbio? Nem nos tempos remotos nem hoje sou capaz de vislumbrar realidades que me deem provas contra a inteireza e a boa fama de Édipo [...]" (485-489). Ao fim desse primeiro canto, o coro, como uma comissão de juízes, nega o caso contra Édipo (511-512), mas é significativo considerarmos a mudança de perspectiva que esse episódio representa para a continuidade do processo jurídico.

\section{O debate com Creonte}

Creonte é introduzido na cena inicialmente dirigindo-se ao povo tebano ( $\pi \mathrm{o} \lambda \tilde{i} \tau \alpha$ ), e depois chamando Édipo por seu nome completo ( $\tau$ ṕpavvov Oíínovv) (513-514). Observa Segal (2001, pp. 84-85) que, diferentemente do mundo misterioso do cego Tirésias, o diálogo com Creonte acontece estritamente no campo do humano e do político e familiariza o espectador ateniense com o debate jurídico. A conjuntura favorece para que Édipo construa um clima de desconfiança. Apesar de estar no controle, sua irritação e suas suspeitas o fazem tomar todas as precauções contra o que ele imagina ser uma conspiração. Mas o que o faz pensar dessa forma? Creonte é seu provável sucessor e, além do mais, Tirésias e ele se conhecem desde antes de sua chegada (288-289). A crise da cidade é um tempo propício para um golpe de Estado. Pode ser também que Creonte e o adivinho tenham armado tudo contra Laio e no momento de tomar o poder tenham sido impedidos pela chegada de Édipo. É bem provável que seja este o raciocínio que o público ateniense, acostumado com as maquinações políticas, espera do protagonista neste momento.

Foucault também acredita que o embate entre Édipo e Creonte é carregado de características judiciárias. Contudo, ele chama a atenção para o fato de que 
Creonte não depõe como uma testemunha no processo, mas como alguém que se sente caluniado e, por isso, no direito de refutar as acusações (Foucault, 2012b, p. 52). "Fiquei sabendo, cidadãos, que nosso rei lançava contra mim acusações terríveis; não me disponho a suportá-las; eis-me aqui" (513-514). Knox (2002, p. 75), por sua vez, enxerga nas palavras de Creonte o tom familiar de indignação, comumente utilizado pelo réu ateniense ao fazer sua argumentação introdutória injuriada em defesa de sua inocência.

Com a expressão $\varphi \theta$ óvo $\zeta$, Édipo traduz o fantasma do sentimento que o assombra. Ele acredita que Creonte tem inveja de sua soberania, de sua inteligência e de seu prestígio, conquistados após a vitória sobre a Esfinge. Além disso, suspeita que o cunhado tenha planejado um complô para tirar-lhe a vida (572-573) e o recrimina por querer visivelmente roubar-lhe o poder (618-622). Se o protesto indignado de Édipo contra o atrevimento de Creonte em argumentar em causa própria e o emprego da palavra assassino são características comuns das salas de audiência gregas (Knox, 2002, p. 75), Foucault constata que, somado a isso, o rei denuncia Creonte de manobra fraudulenta e de suborno de testemunha. "[...] Sem haver entendimento entre ele e ti jamais afirmaria ele que fui eu o causador da morte trágica de Laio" (572-573). Dentro dos padrões de defesa das câmaras processuais, Édipo o repreende por ter falsificado o sentido do oráculo.

Solicitando igualdade de condições por considerar-se semelhante ao rei (581), Creonte tem respostas astutas para as acusações de Édipo. Sobre o suposto suborno de Tirésias, instiga Édipo a investigar qualquer vestígio de uma possível associação entre eles no passado. E em relação à delação de falsificar o oráculo, numa atitude também comum nos tribunais, arrola uma testemunha em sua defesa, que neste caso trata-se do próprio Apolo. "Queres prova? Sem demora vai ao Delfos e informa-te se relatei fielmente o oráculo" (603-604).

Anteriormente, apontamos que, para Foucault, o surgimento da arte de testemunhar tem relação direta com o desenvolvimento da retórica. E é exatamente isso que o discurso de defesa pronunciado por Creonte vem nos comprovar. Ele é uma demonstração clara da nova retórica sofística. Com um argumento reconhecidamente probabilístico, Creonte faz um jogo de perguntas, nas quais tenta provar que, para ele, pouco vale sentir inveja de Édipo, muito menos desejar seu poder, tampouco tomar seu lugar no trono,

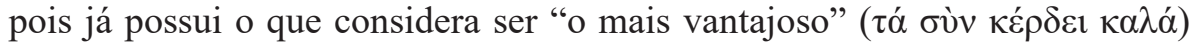
(595). "[...] Já sou por todos festejado, já me acolhem todos solícitos, e tudo que precisam de ti primeiro me procuram; todos eles conseguem tudo por interferência minha [...]” (596-598). Essa lógica de raciocínio, explica-nos Foucault, representa uma forma de defesa tipicamente refinada, cujo intuito é 
desviar o foco da acusação, mostrando o quanto é improvável se fazer aquilo pelo que se está sendo incriminado (2012b, p. 63).

O coro aprova o discurso de Creonte e recomenda cautela ao rei. Entretanto, desacreditado por Édipo, Creonte então pede, dentre as penas previstas pelo oráculo, a mais leve, ou seja, o exílio. Édipo, numa decisão contrária, apela para a sentença mais dura: "Desejo tua morte, e não teu exílio" (623).

\section{Jocasta: juíza e advogada}

A entrada de Jocasta na peça remete-nos imediatamente à figura clássica do juiz. Suas palavras de abertura impõem autoridade sobre os dois adversários e interrompem o fim do julgamento. Ambas as partes então voltam seus argumentos para ela. Creonte reclama do tratamento recebido por Édipo: [...] "parece justo ao teu esposo, minha irmã, tratar-me rudemente" (639-640), e este defende-se afirmando ter convicção "de que ele tramou a minha queda

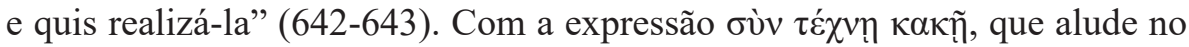
texto de Sófocles a um termo técnico-judicial que nos lança às câmaras processuais do século V, Édipo confirma sua alegação de que Creonte se utilizou de Tirésias para falsear as palavras do oráculo.

A atmosfera de tribunal continua enquanto Creonte faz seu juramento de inocência, "não tenha eu agora bem algum e morra maldito pelos deuses se de qualquer forma mereço essas acusações sem fundamento" (644-645). Jocasta e o coro invocam o respeito de Édipo ao juramento feito. Ele volta atrás na pena estabelecida, mas afirma fazê-lo não pela misericórdia ao condenado, mas por sentir-se comovido ante os clamores do coro: "[...] é a tua prece que me toca e não a dele, que me excita piedade [...]" (671-672).

Ao ser acusado por Édipo, Creonte propõe-se a jurar, dispensando, assim, a necessidade do estabelecimento da verdade a partir de uma testemunha. Os dois estão, dessa forma, implicados no antigo sistema judiciário da promessa e da maldição. Jocasta, como o venerando Fenice, do episódio homérico da disputa entre Menelau e Antíloco, observa e aceita o jogo, tornando-se a responsável pela regularidade dele. Curiosamente, na versão posterior de Sêneca para a tragédia, é possível se ver ainda nesta passagem, ao fim do diálogo entre os dois, a menção a outro símbolo característico do procedimento arcaico de juramento: o bastão. Creonte afirma: "quem empunha o cetro com cruel dureza, teme ele mesmo a aqueles que o temem; o terror se volta contra quem o criou" (Sêneca, 2012, p. 48).

É verdade que Foucault vê, mesmo passados alguns séculos, o juramento purgatório realizado por Creonte como uma variação do modelo de litígio 
realizado entre os guerreiros. Em relação a este, falta, contudo, o que ele chama de elemento principal: "que o acusador aceite este modo de liquidação, e que ele próprio convide o acusado para o desafio" (Foucault, 2011, p. 245). Édipo, que trouxe as suspeitas, não só não propõe ele mesmo a Creonte a prova do juramento, como também inicialmente a rejeita, aceitando-a somente depois das súplicas de Jocasta e do Corifeu. Tal atitude de Édipo revela sua descrença tanto nesse modelo da prova como nas adivinhações de Tirésias. Em ambos os casos, ele se sente ameaçado. "Não deves ignorar então, que pedes simultaneamente minha morte e meu exílio" (658-659). É, pois, por este procedimento relativamente mais tardio no direito grego e na presença de Jocasta e do coro, que Creonte encerra sua contestação com Édipo.

A continuidade do diálogo entre Édipo e Jocasta é recorrente no padrão familiar já conhecido da peça, em que um personagem tenta obter respostas e o entrevistado é relutante em dizer. Nesse caso, e inversamente ao que vimos na cena do embate entre o rei e o adivinho, agora a interrogadora é Jocasta e Édipo é quem deve dar satisfações. Com a insistência da rainha por informações, ele se apresenta um homem amedrontado e confuso ante a acusação que no momento lhe recai: "ele me incrimina, a mim, de ter matado Laio" (703).

Knox recorda que Jocasta age, em sua fala, como uma advogada de def-

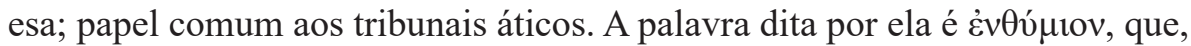
utilizada exatamente em julgamentos por assassinato no século $\mathrm{V}$, carrega um sentido funesto e "descreve o distúrbio mental que o espírito vingativo do homem assassinado supostamente produz em seu assassino" (Knox, 2002, p. 81). No intuito de livrar Édipo de sua angústia ao saber que a acusação parte de Tirésias, seu esforço inicial é o de descaracterização do poder do adivinho: "ouve-me atentamente e ficarás sabendo que o dom divinatório não foi concedido a nenhum dos mortais" (708-709). Porém, na continuidade e quase que casualmente, ela revela um detalhe terrível sobre a morte do antigo rei: "[...] apesar desses oráculos notórios, todos afirmam que assaltantes de outras terras mataram Laio há anos numa encruzilhada" (715-716).

O relato de Jocasta, que, na tentativa de trazer alívio, encaminha ao desastre, é rico no sentido forense. Ao contar como Laio foi morto, temos, pela primeira vez, a narração do oráculo na peça. A predição, a encruzilhada, os assaltantes, o filho renegado, os tornozelos amarrados, a criança que não se torna a assassina do pai, a montanha; são alguns dos detalhes contados por ela e que trazem consigo uma série de informações novas ao julgamento. Além disso, suas palavras causam, também pela primeira vez, o vacilo de Édipo em seu poder e em sua confiança. Confiança esta que a partir deste momento jamais se igualará aos episódios iniciais. "Minha alma encheu-se de temores e a aflição 
subiu-me à mente ouvindo-te falar, senhora..." (726-727). Mesmo apreensivo e agindo na defensiva, Édipo é quem volta a interrogar. Rápido e eficiente, ele se esforça por compreender as circunstâncias nas quais se passou o crime e especula, com Jocasta, o local e a hora do assassinato, a idade e a descrição da vítima, além da quantidade de pessoas que acompanhavam o rei.

Noutro movimento de inversão, e agora atendendo novamente ao pedido da rainha, Édipo inicia seu relato do acontecido na encruzilhada e os motivos que o levaram até lá. Naturalmente, sua atenção se desvia da crise que aflige Tebas para seu passado, ou seja, para a sua história enigmática de vida. "Meu pai é Políbio, coríntio, minha mãe Mérope, dórica [...]” (774-775). Na descrição que ele faz do destino oracular, pela primeira vez há referência ao incesto (791), contudo, nota-se que Édipo não se prende nesse aspecto. Sua maior preocupação é a de que ele pode ser o assassino de Laio e, por isso, vítima da maldição que ele mesmo pronunciou contra o assassino, na praça do mercado.

Confissão e legítima defesa. Estes são dois elementos do discurso de Édipo que mantêm o clima judicial na peça (798-811). Frente a isso, há um paradoxo a ser resolvido. Se o assassinado é mesmo Laio, nem o argumento da própria defesa o livra de sua sentença: o banimento de Tebas. Em contrapartida, também não pode voltar a Corinto, pois lá, acredita ele, está fadado ao destino do oráculo. “[...] E terei de exilar-me em minha vida errante. Não poderei jamais voltar a ver os meus nem pôr de novo os pés no chão de minha pátria [...]" (823-825). O termo técnico-judicial para expressar esse procedimento é $\dot{\varepsilon} \mu \beta \alpha \tau \varepsilon v ́ \varepsilon ı v$, que na lei grega significa "tomar posse do patrimônio paterno" (Knox, 2002, p. 81).

Parece-nos claro que Foucault enxerga nessa cena a legitimação do papel que o testemunho adquire nos processos judiciais gregos, especialmente no que se refere à função da memória para o estabelecimento da verdade. Édipo interroga Jocasta e lhe coloca certo número de questões sobre a morte de Laio: o que lhe disseram, quais foram os rumores públicos, a descrição física do rei assassinado, quem o acompanhava, que pessoas sobreviveram. Depois do oráculo de Tirésias, essa parte da história trazida pela lembrança de Jocasta encerra, mais uma vez, toda a verdade sobre os fatos. "O assassinato de Laio se estabelece primeiro pelas lembranças de Jocasta; lembranças indiretas do que ela ouviu dizer ou do que se reportou a ela: um assassinato na intersecção dos três caminhos" (Foucault, 2011, p. 227). Há, no entanto, um elemento ambíguo que impede Édipo e Jocasta de aceitarem a verdade dessa forma. A rainha fala, em seu testemunho, de um único assaltante, enquanto o que se recorda publicamente é que teriam sido muitas pessoas. "Ouvi de ti há pouco 
que, segundo ele, os assassinos foram vários assaltantes. Se ele vier e reiterar a afirmação, o criminoso não sou eu; somente um homem não equivale a vários [...]" (843-845).

Podemos identificar, na relação solidária que aponta Foucault entre memória e testemunho, um elemento decisivo no desenvolvimento do julgamento. A verdade, que até este momento no texto trágico de Sófocles é resultado de um discurso do tipo profético e prescritivo, agora depende necessariamente de uma enunciação retrospectiva, ou seja, avança sobre a ordem da lembrança e do testemunho. Temos, assim, mudança capital na prática de julgar. A memória ocupa uma função social específica dentro do direito grego. Destaca-se assim a figura do í $\tau \omega \rho$, que, para Marcel Detienne, é aquele que vê e que escuta, ou seja, guarda suas lembranças do passado em virtude de uma decisão de justiça e, por isso, torna-se igualmente uma testemunha. $\mathrm{Na}$ verdade narrada por essa pessoa, "atestam-se, pelo menos, dois componentes: o não esquecimento e, complementarmente, o relato completo, exaustivo, o relato daquilo que realmente se passou" (Detienne, 2006, p. 180). ${ }^{5}$

A negação do oráculo por parte de Jocasta traz como fundamento o fato de que as predições do adivinho são carentes de provas. Isso exige que a testemunha ocular, já mencionada no texto de Sófocles, seja enfim interrogada. Jocasta acredita ser desnecessária tal atitude, pois sabe que a versão dos fatos narrados na época do crime não será alterada. "Ele falou exatamente como eu disse e agora não irá mudar o seu relato" (848-849). Mas é o próprio Édipo que insiste e convence Jocasta da necessidade de ouvi-lo (859-860). Há, evidentemente, um pequeno detalhe, sobre a quantidade de ladrões que atacaram Laio a ser esclarecido e somente o que está guardado na memória do pastor poderá resolver a questão. "Com efeito, só isto me resta de esperança, aguardar este homem, o pastor, é tudo" (836-837).

\section{Uma crítica à tirania}

O segundo estásimo do coro, observa Foucault, é simétrico à primeira intervenção, porém menos claro. $\mathrm{O}$ canto anterior começa por afirmar a força dos deuses, evocando a flecha lançada do Olimpo e que aguarda aquele ao qual ela está destinada. No segundo canto, o texto é inverso. O coro se posiciona mediante uma maldição pronunciada contra o excesso; a arrogância dos

5 Neste ponto, vale a pena considerar que Foucault compreende o îøtwp como uma figura presente somente nos antigos modelos de julgamento e com um papel indefinido, enquanto Detienne o localiza já nos "processos de laicização", ou seja, neste período de transição para o século $V$ e com uma função específica. 
tiranos que se elevam ao alto da fortuna para depois serem lançados ao mais baixo (Foucault, 2012b, p. 61). "O orgulho é o alimento do tirano; quando ele faz exagerada messe de abusos e temeridades fátuas inevitavelmente precipita-se dos píncaros no abismo mais profundo de males de onde nunca mais sairá" (872-878). Na sequência do canto, retoma-se a necessidade do respeito aos oráculos e faz-se conhecer a maldição para aqueles que não aceitam a sua lição. O coro, desta vez, não toma mais partido de Édipo, na medida em que critica a tirania e elogia os oráculos.

A leitura do estásimo realizada por Segal (2001, p. 92) endossa a perspectiva de Foucault e acrescenta outros elementos. Para ele, enquanto prepara a chegada do pastor, esse canto trágico reflete a complexidade de conteúdo e a ambiguidade de sentido daquele que pode ser considerado um dos poemas mais controversos do conjunto das peças de Sófocles. Na superfície, ele é uma oração que evoca a piedade e a justiça, em que os maus são punidos e os oráculos são um sinal legítimo da presença dos deuses na vida dos humanos. Mais profundamente, recorda as atitudes necessárias para com os oráculos e para com a ordem divina, polarizadas entre a crença no poder divino e a crença de que tudo na vida é aleatório, de que acontece por acaso. É um canto que concentra em si maneiras opostas de tentar dar sentido ao sofrimento, por vezes carente de uma explicação humanamente lógica. Os oráculos, na perspectiva atemporal dos deuses, já foram cumpridos, mas os protagonistas, em contrapartida, são aos poucos capturados em sua finitude, num esforço para desvendar os mistérios de seu passado a fim de compreender o que são no presente.

Em meio aos aspectos políticos, éticos e religiosos que o canto trágico proclama, há ainda uma dimensão jurídica que diz respeito à conduta de Édipo e de Jocasta. De um lado, está o rei, acusado de assassinar quatro ou cinco pessoas, dentre as quais seu antecessor; de outro, está a rainha, que, no mínimo, apresenta-se como cúmplice na morte de um bebê, possível sucessor de Laio no trono de Tebas. O coro clama, então, por pureza e castidade ( $\dot{\alpha} \gamma v \varepsilon i ́ \alpha v)$, pois, na sobreposição jurídico-religiosa do século $\mathrm{V}$, tirar a vida de alguém significa o pior sinal de impureza. "Deixe o destino que sempre eu conserve a santa pureza em todas as minhas palavras e todos os meus atos [...]” (863-864).

A inversão legal na postura do coro é outra característica desta cena. Se no primeiro estásimo ele age como juiz, poupando Édipo de qualquer sentença, neste segundo canto sua manifestação lembra um promotor, exigindo a condenação do culpado e justificando, dessa forma, a autoridade que lhe é concedida. Como as leis humanas foram insuficientes e tornaramse arcaicas para resolver tanto o crime do abandono do filho de Laio como o 
assassinato do rei, a única solução plausível neste momento, canta a estrofe, é a intervenção divina. "Somente o céu gerou as santas leis; não poderia a condição dos homens, simples mortais, falíveis, produzi-las" (866-871). No apelo promotoral ao juiz supremo, neste caso Zeus, eles se utilizam da

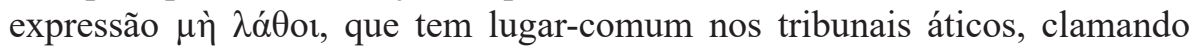
para que nada escape à observação de seu poder absoluto e eterno (904).

\section{Os testemunhos finais: as palavras do Citerão}

Os diálogos que se seguem são determinantes para a mudança de rumo do inquérito. Eles trazem à luz, com os testemunhos do mensageiro de Corinto e do pastor de Citerão, a verdade sobre o passado de Édipo e fazem emergir o ápice da ironia dramática da peça. Jocasta, nesta altura, necessita de pouco para juntar as partes que faltam para compreender o contexto mórbido no qual sua vida está mergulhada, e Édipo permanece um pouco mais no palco, com um ingênuo otimismo. Essa postura do herói de Sófocles adequa-se à série de enganos que ele parece cometer na triagem dos fatos. Tomado pelo medo, sua rapidez, nada comparada com seus traços investigativos do início da trama, impede-o de tomar o devido cuidado nas análises das provas que se apresentam a sua frente.

O mensageiro de Corinto, que antecede inesperadamente o pastor, e por isso mesmo atrasa o testemunho da pessoa "que viu", traz uma informação nova e não menos terrível à investigação: a origem tebana de Édipo (Foucault, 2011, p. 227). Nota-se que o mensageiro de Corinto não se aproxima em nada dos mensageiros que comumente compõem as tragédias gregas. Sófocles possivelmente criou essa figura, que garante no enredo um intenso diálogo apurativo, cheio de detalhes. Ele não é um simples portador de notícias, mas antes alguém com uma história própria de vida, ligada, por certos laços, principalmente a Édipo e a Jocasta. "Sua participação justapõe, de maneira brilhante, a morte inocente e pacífica de Políbio com a morte violenta de Laio" (Segal, 2001, pp. 94-95).

Para Jocasta, a revelação do mensageiro basta para que ela perceba a gravidade dos fatos. Édipo é seu filho-esposo e assassino de Laio. O oráculo se cumpriu. Desesperada, ela se retira imediatamente para o palácio e lá comete suicídio, enquanto Édipo, sem compreender ainda a dramaticidade do que está acontecendo, alimenta irracionalmente um resquício de esperança, compartilhada pelo coro: "Iremos festejar-te e dançaremos no chão que alimentou nosso senhor. Sê-nos propício, Febo protetor!” (1094-1098). A 
dedução de ambos parece simples: ainda que humilhante, o crime está na descendência de Édipo, possivelmente filho de um escravo (1076-1085).

O julgamento está quase no fim, mas Édipo está obstinado pela solução final, por isso, manda convocar o pastor de Citerão para o interrogatório no intuito de esclarecer tanto as informações que faltam sobre sua origem como o que resta saber sobre o assassinato de Laio.

O ambiente judicial é perfeitamente identificado por Foucault na inquirição do pastor (2012b, p. 68). Primeiramente, há o interrogatório de identidade. Ante o argumento de Édipo de não o conhecer, cabe ao coro e ao mensageiro de Corinto executarem essa tarefa. Eles confirmam que o ancião realmente é a pessoa que acompanhava o rei no dia de sua morte. Em seguida, o próprio pastor é convidado a ratificar a informação: "Olhe-me bem ancião; responde a umas perguntas que te farei: Serviste antigamente a Laio?" (11211122). Ao que ele responde: "Eu era seu escravo; ele não me comprou; desde pequeno fui criado em casa dele" (1123). O último estágio de reconhecimento é a palavra do mensageiro dirigida ao pastor: "[...] Lembras-te de que deste uma criança um dia para eu tratar como se fosse filho meu? [...] Aqui está a frágil criancinha, amigo" (1142-1143).

Em segundo lugar, assiste-se ao interrogatório sobre o que se passou. Como observa Foucault, trata-se de um procedimento que tem sua base na memória. Típico de uma testemunha acuada no tribunal, o pastor se recusa a dizer o que sabe; primeiro porque cometeu a falta de não matar Édipo, como lhe tinha sido solicitado por Laio e Jocasta, e, depois, porque ele sabe bem que o que disser desencadeará a catástrofe. A Tirésias, por sua condição divina, foi dada a possibilidade de dizer "eu não te obedeço e por isso nego-me a responder às perguntas", enquanto o pastor vê-se obrigado a dar satisfações. Como se apresenta relutante em falar, Édipo ameaça torturá-lo.

$\mathrm{O}$ que vemos em seguida, diz Foucault, é um interrogatório marcado pela ameaça e pelo constrangimento, comum aos julgamentos áticos, principalmente quando o interrogado é um escravo (2012b, p. 69). Era possível, de acordo com a lei da época, torturar para se conseguir uma confissão, desde que o senhor do escravo assim permitisse (Glotz, 1980, p. 213). É o que vemos nesta cena. Édipo tem o poder sobre o criado e o ameaça de morte caso insista em silenciar. "Preferes responder por bem ou constrangido?" (1152). Entendendo a mensagem, o pastor clama por piedade: "Não deves maltratar um velho! Tem piedade!” (1153). Mesmo assim, alguns breves diálogos mais tarde, o rei impõe a punição: "Não vamos amarrar-lhe logo as mãos às costas"? (1154). Já vítima das preliminares de tortura, o velho homem decide responder às questões feitas por Édipo. 
Para Glotz, o testemunho judicial de um criado tem pleno valor somente sob tortura, até porque, dessa forma, garante-se que o depoimento seja sempre a favor do torturador (1980, p. 213). No caso de Édipo, curiosamente, o procedimento segue a lógica inversa. O escravo, mesmo resistente, é forçado a revelar a verdade que incrimina aquele que o tortura (Knox, 2002, p. 85). Utilizando uma terminologia técnico-legal $\pi \varepsilon ́ \phi \alpha \sigma \mu \alpha \iota$, Édipo depara-se com sua própria verdade. "Ai de mim! Ai de mim! As dúvidas desfazem-se!" (1182).

\section{Considerações finais}

Nas interpretações de Michel Foucault acerca da tragédia de Sófocles, principalmente em sua primeira fase genealógica, notamos, não por acaso, que o traço fundamental do saber edipiano é exatamente o do poder político, ou seja, o saber-poder tirânico. Talvez por isso mesmo, para o pensador francês, "Édipo-Rei" deve ser considerada, antes de tudo, uma história do poder: "[...] Édipo é o homem do poder, homem que exerce certo tipo de poder. [...] Podemos notar a importância do poder no decorrer de toda peça. Durante toda peça o que está em questão é essencialmente o poder de Édipo e é isso que faz com que ele se sinta ameaçado" (Foucault, 2002, p. 41). Vemos, dessa forma, como Édipo, desde seu saber específico, toma e perde o poder. E entre o ignorante de seu passado e o sabedor em demasia, capaz de encontrar com sua inteligência as pistas do criminoso que, ironicamente, levam para si mesmo, concebe-se, a partir desse momento, uma nova forma do fazer político. A queda de Édipo, rei amado e querido por seu povo, assinala a dura crítica à tirania, que, desviando-se dos preceitos divinos, torna-se um sistema inapto de governo.

Nesse contexto, que nascem para Foucault as práticas jurídicas do inquérito (enquête) e do testemunho, alterando de maneira significativa a relação entre saber e poder. Para ele, "Édipo-Rei" é "fundamentalmente o primeiro testemunho que temos das práticas judiciárias gregas", sendo "um procedimento de pesquisa da verdade que obedece exatamente as práticas judiciárias gregas dessa época" (Foucault, 2002, p. 31). Em torno da revelação do responsável por um crime e a punição do criminoso, desenvolve-se um conjunto de procedimentos, rigorosamente consonantes com as leis da época, que demarcam a passagem do pré-direito para o direito, da palavra-mágica para a palavra-diálogo, do juramento decisório para o julgamento testemunhal. Com isso, a figura da testemunha adquire uma importância definitiva para a conservação dos fatos, marcando definitivamente as formas de produção da verdade no Ocidente. 


\section{Referências}

ARISTÓTELES. "Poética". Trad. Ana Maria Valente. Lisboa: Calouste Gulbenkian, 2004.

DETIENNE, M. "Les maîtres de vérité dans la Grèce archaïque". Paris: Le Livre de Poche, 2006.

FOUCAULT, M. "A verdade e as formas jurídicas". Trad. Roberto Cabral de Melo Machado e Eduardo Jardim Morais. Rio de Janeiro: Nau Editora, 2002.

. "Leçons sur La Volonté de Savoir. Cours au Collège de France. 1970-1971".

Paris: Gallimard; Seuil, 2011.

. "Du Gouvernement des vivants. Cours au Collège de France. 1979-1980".

Paris: Gallimard; Seuil, 2012a.

. "Mal faire, dire vrai. Fonction de l'aveu en justice". Louvain, Belgique:

Presses Universitaires de Louvain, 2012 b.

GERNET, L. "Recherches sur le développement de la pensée juridique en Grèce ancienne". Paris: Albin Michel, 2001.

GLOTZ, G. "A cidade grega". Trad. Henrique de Araújo Mesquita e Roberto Cortes de Lacerda.São Paulo: DIFEL, 1980.

JEBB, R. C. "The Oedipus Tyrannus". Cambrigde: At University Press, 1885.

KNOX, B. "Édipo em Tebas”. Trad. Margarida Goldsztyn. São Paulo: Perspectiva, 2002.

SEGAL, C. "Oedipus Tyrannus: tragic heroism and the limits of knowledge". New York: Oxford University Press, 2001.

SÊNECA. "Édipo". Edições Kindle, 2012.

SÓFOCLES. "A trilogia Tebana. Édipo-Rei, Édipo em Colono, Antígona”. Rio de Janeiro: Jorge Zahar, 1989.

. "Édipo-Rei”. Trad. Donaldo Schüler. Rio de Janeiro: Lamparina, 2004.

. "Édipo-Rei de Sófocles". Trad. Trajano Vieira. São Paulo: Perspectiva, 2012.

(Edição bilíngue Grego-Português).

SOPHOCLE. "Tragédies”. Paris: Les Belles Lettres, 1962.

Francês).

“Edipe Roi”. Paris: Les Belles Lettres, 2007. (Edição bilíngue Grego-

VERNANT, J.-P., VIDAL-NAQUET, P. "Mito e tragédia na Grécia Antiga". Trad. Anna Lia A. de Almeida Prado et al. São Paulo: Perspectiva, 1999. 